\title{
High-temperature bioleaching of nickel sulfides: thermodynamic and kinetic implications
}

\author{
Flávio L.S. Cruz ${ }^{\text {a }}$, Victor A. Oliveira ${ }^{a}$, Damaris Guimarães ${ }^{a}$, Adelson D. Souza ${ }^{\text {b }}$, Versiane A. Leão ${ }^{\text {a,* }}$ \\ a Bio E' Hydrometallurgy Laboratories, Universidade Federal de Ouro Preto. Campus Morro do Cruzeiro, s.n., Ouro Preto, MG 35400-000, Brazil \\ b Votorantim Metais-Technologies Development Center, BR 040, Km 274-Três Marias, MG, 39205-000, Brazil
}

\section{A R T I C L E I N F O}

Article history:

Received 5 July 2010

Received in revised form 18 August 2010

Accepted 18 August 2010

Available online 24 August 2010

\section{Keywords:}

Mesophiles

Moderate thermophiles

Nickel sulfides

Bioleaching

Cyclic voltammetry

\begin{abstract}
A B S T R A C T
The effect of temperature on nickel sulfide bioleaching was studied in the presence of mesophile (Acidithiobacillus ferrooxidans) and moderate thermophile (Sulfobacillus thermosulfidooxidans) strains and the results were discussed in terms of sulfide dissolution thermodynamics (Eh-pH diagrams) and kinetics (cyclic voltammetry). It was observed that in the $\mathrm{pH}$ range 1.8-2.0 the highest nickel dissolution was achieved which reached $50 \%$ for mesophiles and over $80 \%$ for moderate thermophiles. External ferrous iron addition had no effect on the metal dissolution at $34{ }^{\circ} \mathrm{C}$, but adversely affected nickel leaching at higher temperatures. The best outcomes were accomplished with low $\mathrm{FeSO}_{4}$ additions $(2.5 \mathrm{~g} / \mathrm{L})$ at $50{ }^{\circ} \mathrm{C}$. Pyrrhotite dissolution avoided the need for external iron addition, providing $\mathrm{Fe}^{2+}$ concentrations as high as $7 \mathrm{~g} / \mathrm{L}$ during bioleaching, which supports bacterial growth. Eh-pH diagrams for pentlandite and pyrrhotite show a negligible effect of temperature on the stability field of each sulfide whilst cyclic voltammetry indicated that temperature has the strongest influence on pyrrhotite oxidation. The latter along with a rapid increase in solution potential (Eh) explains the higher and faster extraction observed with S. thermosulfidooxidans.
\end{abstract}

(c) 2010 Elsevier B.V. All rights reserved.

\section{Introduction}

Nickel is mainly applied in stainless steel production and the metal is produced by either pyrometallurgical (flash smelting) or hydrometallurgical processes such as (i) high-pressure acid leach (HPAL) or (ii) Caron Process for laterite ores, as well as (iii) oxidative leaching of sulfide ores. Furthermore, as high-grade nickel concentrates are becoming scarce, the development of new hydrometallurgical processes is becoming compelling, especially to treat low-grade or complex nickel ores. Recently, the Talvivaara start-up project in Finland has brought attention to nickel heap bioleaching. This environment-friendly biotechnology is suited to low-grade nickel sulfide ores due to its moderate capital investment, low operation costs and relatively simple operation procedures (Watling, 2008). Nickel sulfide bioleaching is impacted by the complex ore mineralogy where different sulfide minerals form mineralogical associations and thus galvanic interactions are usually present during leaching (Santos et al., 2006).

Different biotechnologies for nickel sulfide processing have been tested. Two bioleaching trials performed with BioHeap ${ }^{\mathrm{TM}}$ technology were run in Western Australia-the Radio Hill and Sherlock Bay projects. Radio Hill applied moderately thermophilic (Sulfobacillus and Thermoplasma) cultures at $50-55{ }^{\circ} \mathrm{C}$ to achieve $90 \%$ nickel

\footnotetext{
* Corresponding author. Tel.: + 55313559 1102; fax: +55 3135591561. E-mail addresses: versiane@demet.em.ufop.br, va.leao@uol.com.br (V.A. Leão).
}

recovery in a year's time. The Sherlock Bay trial applied a salt tolerant mixed culture to bioleach a $0.4 \%$ disseminated nickel sulfide ore, achieving $88 \%$ metal recovery in 400 days (Watling, 2008).

Notwithstanding, the first industrial application of heap bioleaching technology is the Talvivaara project. In 2005, a 17,000 ton demonstration plant was constructed, consisting of an 8-m-tall heap stacked with an $80 \%<8 \mathrm{~mm}$ agglomerated ore sample, inoculated with indigenous bacteria, collected from the mine site (mesophilic and thermophilic strains). Bioleaching could be accomplished even under harsh winter conditions, due to the oxidation of the large quantity of pyrrhotite and pyrite that resulted in temperatures of over $50{ }^{\circ} \mathrm{C}$ in the pregnant leach solution (Riekkola-Vanhanen, 2007). The first metal was produced in October 2008 and heap bioleaching has been performed in two stages; namely, a primary heap pad with a residence time of 1.5 years and a secondary pad with a residence time of 3.5 years.

As high temperatures can be observed during industrial heap bioleaching, this study addresses the bioleaching of a complex nickel concentrate containing pentlandite and pyrrhotite, focusing on the temperature effects on nickel dissolution with iron- and sulfuroxidizing bacteria. It has been found that the temperature improves bioleaching by increasing both leaching kinetics and metal recovery.

\section{Materials and methods}

A complex sulfide concentrate sample, kindly provided by Mineração Serra da Fortaleza (Grupo Votorantim, Brazil), was studied. 
The sample had a particle size of $80 \%<47 \mu \mathrm{m}$ and was used as received. The specific surface area of the solid particles was determined as $2.13 \mathrm{~m}^{2} / \mathrm{g}$ by nitrogen absorption (BET isotherm), in a NOVA 1000 device. The chemical analysis of the concentrate has shown $5.9 \% \mathrm{Ni}, 28.1 \% \mathrm{Fe}, 0.4 \% \mathrm{Co}, 0.1 \% \mathrm{Cu}$ and $21.2 \% \mathrm{~S}$.

$\mathrm{X}$-ray diffraction (XRD) and energy dispersive X-ray spectroscopy (EDS) analyses of the concentrate revealed pentlandite, pyrrhotite and chalcopyrite as the main sulfide phases. Moreover, magnetite and silicates were also observed. The main minerals, pentlandite and pyrrhotite, were not completely liberated, exhibiting very fine and intimately associated grains (Santos et al., 2006). Based on the chemical analysis, the concentrate was estimated as containing $36.6 \%$ silicates, $6.3 \%$ magnetite and $57.0 \%$ sulfides. In addition, the sulfur partition was determined as $70.0 \%$ pyrrhotite, $29.6 \%$ pentlandite and $0.4 \%$ chalcopyrite.

The mesophile microorganisms were isolated from a Brazilian zinc sulfide mine and microbial diversity studies applying DGGE and FISH techniques revealed the presence of both Acidithiobacillus ferrooxidans and $A$. thiooxidans with the predominance of the former (Alves et al., 2009). The thermophile strain was Sulfobacillus thermosulfidooxidans from DSMZ (9293).

Bacterial growth was carried out in a Norris medium $(0.2 \mathrm{~g} / \mathrm{L}$ $\left(\mathrm{NH}_{4}\right) \mathrm{SO}_{4}, 0.4 \mathrm{~g} / \mathrm{L} \mathrm{MgSO}_{4} .7 \mathrm{H}_{2} \mathrm{O}$, and $\left.0.1 \mathrm{~g} / \mathrm{L} \mathrm{K}_{2} \mathrm{HPO}_{4}\right)$, complemented with yeast extract (Difco) $(0.1 \mathrm{~g} / \mathrm{L})$ in the experiments with $S$. thermosulfidooxidans. Growth nutrient solution $(50 \mathrm{~mL})$ was adjusted to the required $\mathrm{pH}$ and transferred to $250 \mathrm{~mL}$ Erlenmeyer flasks and the amount required of $\mathrm{Fe}(\mathrm{II})$ was added as an acid solution containing $50 \mathrm{~g} / \mathrm{L} \mathrm{Fe}$ (II) (as $\mathrm{FeSO}_{4} \cdot 7 \mathrm{H}_{2} \mathrm{O}$ ). Afterwards, $5 \mathrm{~g}$ of the concentrate was added to the flasks which were then inoculated with a $10 \mathrm{~mL}$ aliquot of the selected culture (containing at least $10^{8}$ cell $/ \mathrm{mL}$ ) together with distilled water to reach a final slurry volume of $100 \mathrm{~mL}$. Finally, the $\mathrm{pH}$ was adjusted to the required value and the flask weight was recorded. The $\mathrm{pH}$ (Hanna HI931400) was adjusted using $1 \mathrm{~mol} / \mathrm{L}$ sulfuric acid or $6 \mathrm{~mol} / \mathrm{L}$ sodium hydroxide. The redox potential (Digimed) (vs. an $\mathrm{Ag} / \mathrm{AgCl}$ electrode) was recorded. Two temperature-controlled orbital shakers (New Brunswick) at $34{ }^{\circ} \mathrm{C}$ and $50{ }^{\circ} \mathrm{C}$ provided mixing. Each flask was sampled by removing a $2 \mathrm{~mL}$ aliquot of the leach solution, which was then used for elemental analysis ( $\mathrm{Ni}$ and $\mathrm{Fe}$ ), by atomic absorption spectrometry (Perkin Elmer, AAnalyst 100). Evaporation losses were compensated by the addition of the Norris medium to the recorded weight. Sterile controls were also run in the presence of a thymol solution as bactericide.

Cyclic voltammetry experiments were performed with a Metrohm PGSTAT302N potentiostat controlled by a General Purpose Electrochemical System (GPES) v. 4.9 (Eco Chemie B.V.), at a scan rate of $50 \mathrm{mV} / \mathrm{s}$ over the potential region of -0.6 to $1.4 \mathrm{~V}(\mathrm{Ag} / \mathrm{AgCl})$, starting in the anodic direction. The experiments were run in a water-jacket cell $(50-150 \mathrm{~mL})$ connected to a temperature controlled bath. The cell was a standard electrochemical system containing three electrodes: a platinum counter electrode, an $\mathrm{Ag} / \mathrm{AgCl}$ reference electrode and the work electrode. All potential data was measured with respect to the $\mathrm{Ag} / \mathrm{AgCl}$ reference electrode ( $0.197 \mathrm{~V}$ versus SHE, at $25{ }^{\circ} \mathrm{C}$ ) in a $1 \mathrm{~mol} / \mathrm{L} \mathrm{H}_{2} \mathrm{SO}_{4}$ solution. Due to the powdered nature of the nickel concentrate, carbon-paste electrodes (CPE) were produced by a mixture of the ore $(2.5 \mathrm{~g})$, graphite powder $(2.4 \mathrm{~g})$ and solid paraffin $(1.7 \mathrm{~g})$. Around $200 \mathrm{mg}$ carbon paste was added to a $5 \mathrm{~mm}$ diameter $\left(19.6 \mathrm{~mm}^{2}\right.$ surface area) hollow electrode (Metrohm-D. RDE.BLANK). Prior to the scans, the electrolyte was degassed with high-purity $\mathrm{N}_{2}$ (5.0) for 15 minutes and the gas was kept blowing over the solution surface during the experimental runs.

The morphological features of the leach residues were studied by SEM-EDS with a JEOL JSM 501 SEM microscope. The particles investigated were filtered and observed as powder or mounted in epoxy resin and then polished to a flat, mirrored surface. Energy dispersive X-ray spectroscopy (EDS) was used for elemental analysis.
The software HSC Chemistry 5.0 (Outokumpu Research, Finland) was used to draw the Eh-pH diagrams. Unless otherwise stated, standard free energies of formation $\left(\Delta \mathrm{G}_{\mathrm{f}}^{0}\right)$ for the different species were those provided by the software.

\section{Results and discussion}

\subsection{Bioleaching studies}

The $\mathrm{pH}$ of the solution is an important parameter in bioleaching studies since there is an optimum range within which it can be effectively accomplished. There is a lower limit that controls bacterial growth, around pH 1.6 in the case of Acidithiobacillus sp. (Pina et al., 2005), and bioleaching can be performed at $\mathrm{pH}$ as low as 1.2 with $S$. thermosulfidooxidans. Conversely, for $\mathrm{pH}$ above 2.4, iron(III) starts to precipitate massively as jarosite (Pogliani and Donati, 2000) which may affect bioleaching efficiency (Santos et al., 2008). Therefore, the effect of $\mathrm{pH}$ on nickel bioleaching was assessed with a $2.5 \mathrm{~g} / \mathrm{L} \mathrm{Fe}(\mathrm{II})$ solution in the $\mathrm{pH}$ range 1.2-2.4, as shown in Fig. 1 for both mesophilic and thermophilic microorganisms.

As depicted in Fig. 1, the highest nickel dissolution is observed at a $\mathrm{pH}$ of $2.0-2.2$ with mesophiles $\left(34^{\circ} \mathrm{C}\right)$ and 1.8 with moderate thermophiles $\left(50{ }^{\circ} \mathrm{C}\right.$ ). Nickel dissolution reaches $50 \%$ at 300 hours with mesophiles, while extractions close to $80 \%$ were observed with $S$. thermosulfidooxidans, pointing out the positive effect of temperature on bioleaching (Dew et al., 2000). Temperature has also affected the abiotic nickel leaching, since the control experiment with mesophiles produced only $9 \%$ extraction at $34^{\circ} \mathrm{C}$ (data not shown) and reached $20 \%$ in the experiment at $50{ }^{\circ} \mathrm{C}$. This chemical effect was also observed by (Yang et al., 2008) for the leaching of a low-grade pentlandite ore assaying $0.5 \% \mathrm{Ni}, 2.5 \% \mathrm{Fe}$ and $1.4 \% \mathrm{Mg}$ with a biologically produced sulfate-chloride $\mathrm{Fe}(\mathrm{III})$ solution, where nickel dissolution was improved from $18 \%$ to $45 \%$ as the temperature increased from $34^{\circ} \mathrm{C}$ to $50{ }^{\circ} \mathrm{C}$. Longer leaching periods (800 hours) resulted in 70\% nickel extractions (Santos et al., 2006) with Acidithiobacillus and no increase with $S$. thermosulfidooxidans. The positive effect of temperature on bioleaching experiments was also noticed for copper (Marhual et al., 2008). Studying the bioleaching of a $0.5 \% \mathrm{Cu}$ chalcopyrite ore, Marhual et al. (2008) enriched two different moderate thermophiles and one mesophile consortia with bioleaching activity. They observed 80\% copper dissolution at $50{ }^{\circ} \mathrm{C}$, whereas the yield was $40 \%$ with mesophiles. Therefore, bioleaching at $50{ }^{\circ} \mathrm{C}$ increases metal extraction as compared to that achieved with mesophile strains.

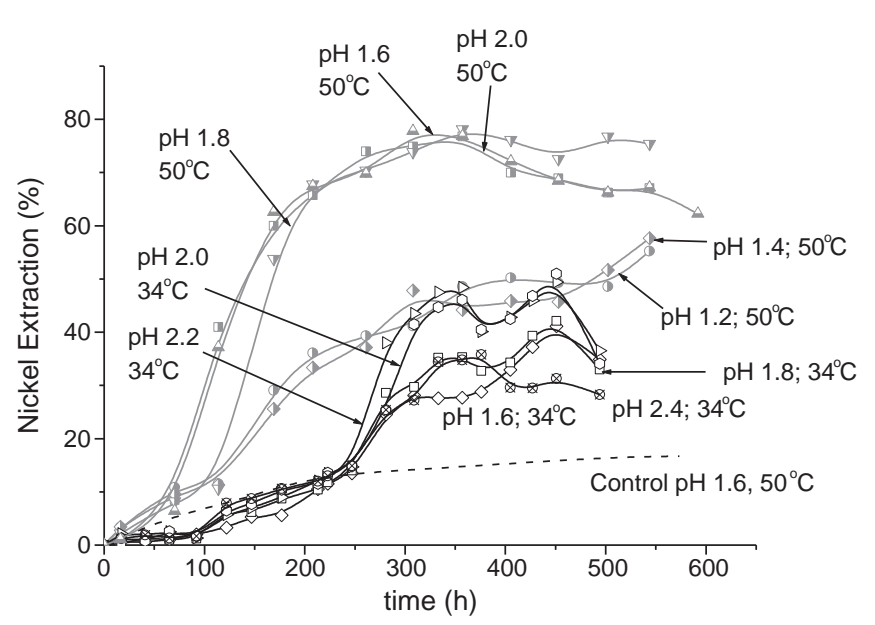

Fig. 1. Effect of $\mathrm{pH}$ on nickel extraction by mesophilic and thermophilic microorganisms $5 \%$ solids w/v, $[\mathrm{Fe}(\mathrm{II})]=2.5 \mathrm{~g} / \mathrm{L}$ and $34{ }^{\circ} \mathrm{C}$ (Acidithiobacillus) $50{ }^{\circ} \mathrm{C}$ (Sulfobacillus). 
The effect of $\mathrm{Fe}^{2+}$ concentration (added as $\mathrm{FeSO}_{4}$ ) on nickel bioleaching is shown in Fig. 2. It can be seen that the $\mathrm{Fe}^{2+}$ external source is not required for leaching with mesophiles; i.e. nickel extraction is not affected by the amount of $\mathrm{Fe}^{2+}$ added to the reacting system. These results suggest that the iron dissolution from the concentrate was sufficient for maintaining a high potential (Deveci et al., 2004), sustaining nickel dissolution. This $\mathrm{Fe}^{2+}$ content is a result of ironcontaining phase dissolution (Santos et al., 2008). Pyrrhotite can be quickly and readily dissolved in acidic solutions, releasing $\mathrm{Fe}^{2+}$ and $\mathrm{H}_{2} \mathrm{~S}$ (Mason and Rice, 2002). As the amount of pyrrhotite could be estimated at around $40 \%$ of the concentrate, it is a source of aqueous $\mathrm{Fe}^{2+}$ and therefore, provides enough substrate for bacterial growth. The lower iron concentration observed at the $\mathrm{pH}$ of 2.0 and $34{ }^{\circ} \mathrm{C}$ (Fig. 3), is ascribed to jarosite formation; especially over the surface of the pentlandite grains (Fig. 4).

Unlike the experiments with mesophiles, the addition of $\mathrm{FeSO}_{4}$ does have an effect on nickel leaching with moderate thermophiles. Fig. 2 indicates that the largest leaching is achieved in the presence of low $\mathrm{Fe}^{2+}$ concentrations, added to the system $(2.5 \mathrm{~g} / \mathrm{L})$. Iron concentration was followed during these experiments and the results are depicted in Fig. 5. It can be seen that regardless of the amount of $\mathrm{FeSO}_{4}$ added to the system, iron concentrations reach $8 \mathrm{~g} / \mathrm{L}$ and even when the salt is not added, $7 \mathrm{~g} / \mathrm{L} \mathrm{Fe}$ is observed in the system. At lower $\mathrm{pH}$, iron concentrations attain values as high as $7.5 \mathrm{~g} / \mathrm{L}$ with mesophiles and $10 \mathrm{~g} / \mathrm{L}$ with moderate thermophiles (Fig. 3). At $50{ }^{\circ} \mathrm{C}$, iron precipitation is observed after 200 hours, when solution potential is over $550 \mathrm{mV}$ (Fig. 6), in all the experiments where $\mathrm{FeSO}_{4}$ was added. Therefore jarosite precipitation accounts for iron removal from the system, covering the concentrate grains (Fig. 4b).

Comparing iron and nickel dissolution, it can be noticed that at $34^{\circ} \mathrm{C}$, iron concentration peaks after around 250 hours (Fig. 3), when nickel dissolution is yet to be started (Fig. 1). This implies that iron is being dissolved from pyrrhotite, since it does not contain appreciable nickel content, as can be noticed in Fig. 4d. This figure shows a leached pyrrhotite grain surrounded by a less attacked pentlandite phase. After 350 hours, iron is almost depleted (Fig. 3), nickel dissolution levels out and elemental sulfur can be noticed in the solid particle (Fig. $4 \mathrm{a}$ and c). Nevertheless, as observed in Fig. 2, nickel and iron profiles are different in the experiments with S. thermosulfidooxidans. After 200 hours, nickel dissolution is around $70 \%$ and Figs. 3 and 5 show that iron is already precipitating from the solution, implying that both minerals (pyrrhotite and pentlandite) are being leached simultaneously. It is worth mentioning that in both temperatures, nickel

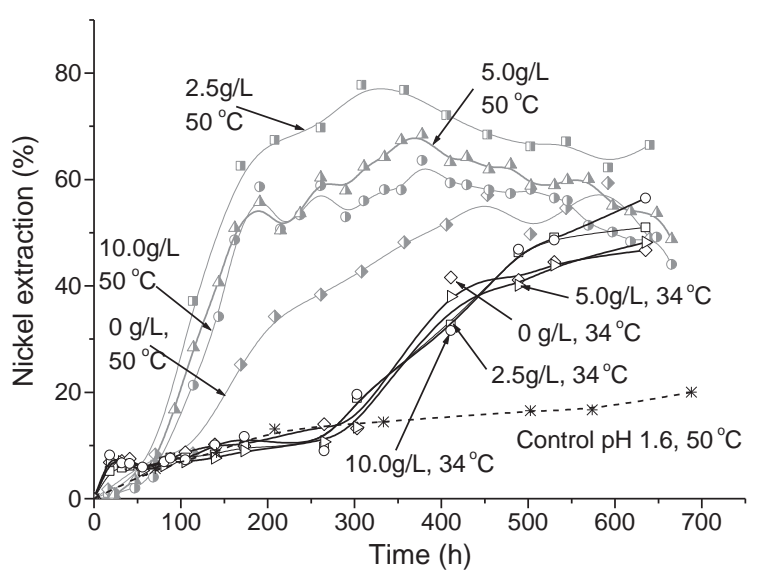

Fig. 2. Effect of added $\mathrm{Fe}(\mathrm{II})$ concentrations on nickel extraction by mesophilic and thermophilic microorganisms $5 \%$ solids w/v, pH 1.8 and $34^{\circ} \mathrm{C}$ (Acidithiobacillus); $\mathrm{pH} 1.6$ and $50{ }^{\circ} \mathrm{C}$ (Sulfobacillus).

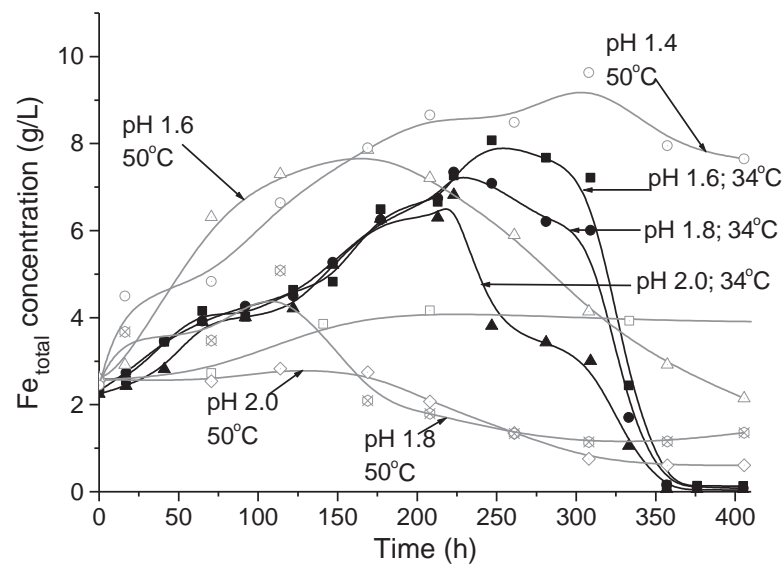

Fig. 3. Effect of pH on iron concentration during bioleaching of nickel concentrate by (a) mesophile iron-oxidizing culture $\left(5 \% \mathrm{w} / \mathrm{v},[\mathrm{Fe}(\mathrm{II})]_{\text {initial }}=2.5 \mathrm{~g} / \mathrm{L}, 34^{\circ} \mathrm{C}\right)$ and $(\mathrm{b})$ moderate thermophile $\left(5 \% \mathrm{w} / \mathrm{v},[\mathrm{Fe}(\mathrm{II})]_{\text {initial }}=2.5 \mathrm{~g} / \mathrm{L}, 50^{\circ} \mathrm{C}\right)$.

dissolution is the largest at the $\mathrm{pH}$ of $1.8-2.0$, when iron concentration is at least $2 \mathrm{~g} / \mathrm{L}$; this concentration seems to be sufficient for effective nickel dissolution despite iron precipitation.

Applying electrochemical techniques, Blázquez et al. (1999) showed the importance of bacteria as a catalyst for sulfur oxidation during $\mathrm{ZnS}$ bioleaching. In the present study, the bacteria did not oxidize all the elemental sulfur formed during leaching, since the latter was always observed as a reaction product (Fig. 4). Hansford and Vargas (2001) states that elemental sulfur oxidation only appreciably occurs in the absence of $\mathrm{Fe}^{2+}$ ions. As the iron is dissolved from the concentrate during pyrrhotite leaching, ferrous iron is always available as a substrate for bacterial growth, hindering elemental sulfur oxidation. As pentlandite and pyrrhotite oxidation produces elemental sulfur (Kuklinskii et al., 2001; Lu et al., 2000; Sand et al., 2001), it could act as a barrier for the diffusion of oxidized products from the mineral surface (Schippers et al., 1996). Therefore, another important role for both bacteria would be elemental sulfur removal, enabling the diffusion of oxidized products from the sulfide and increasing extraction, as a result. This would especially occur after pyrrhotite consumption and the decrease in the ferrous iron concentration, as observed in the experiments with Acidithiobacillus. This would compel the bacteria to oxidize elemental sulfur by the direct mechanism (Berry et al., 1978; Mehta and Murr, 1983). This phenomenon is not so evident in the experiments with $S$. thermosulfooxidans, due to the faster sulfide leaching kinetics observed.

The importance of sulfur-oxidizing bacteria was confirmed in industrial nickel bioleaching operations. A. ferrooxidans and A. caldus (with the predominance of the former) were observed in the Talvivaara project, 2 years after start up (Hallberg et al., 2007). The presence of $A$. caldus supports the finds of the present study, since this is a moderate thermophile bacterium with only sulfur-oxidizing capabilities (Semenza et al., 2002). It would readily thrive in the presence of these sulfides, as well as the elemental sulfur formed during nickel sulfide bioleaching.

An important difference when nickel bioleaching is compared at both temperatures can be observed in Fig. 6, where the change in solution potential along time is presented. It can be noticed that the solution potential (Eh) increases considerably faster in the presence of $S$. thermosulfidooxidans, as compared to the experiments with A. ferrooxidans. At the $\mathrm{pH}$ of 2.0, for instance, 100 hours is required for the potential to reach $500 \mathrm{mV}(\mathrm{Ag} / \mathrm{AgCl})$ with the former $\left(50{ }^{\circ} \mathrm{C}\right)$, whereas the same potential is attained after 200 hours with the latter $\left(34^{\circ} \mathrm{C}\right)$. High potentials indicate high ferric iron concentrations and for those sulfides that do not show strong passivation, which seems to be the case of pentlandite and 
a

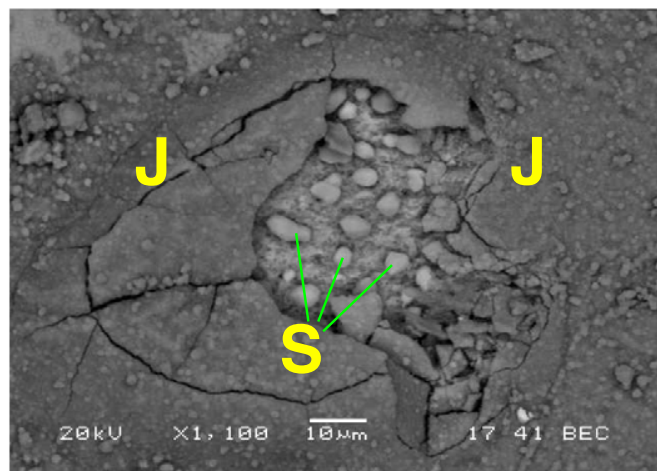

C

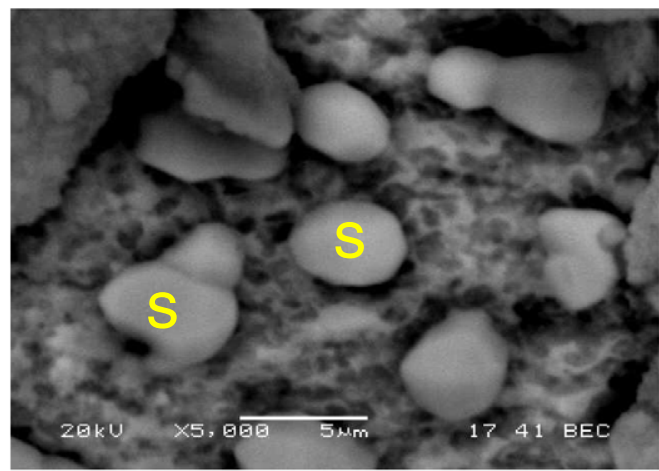

b

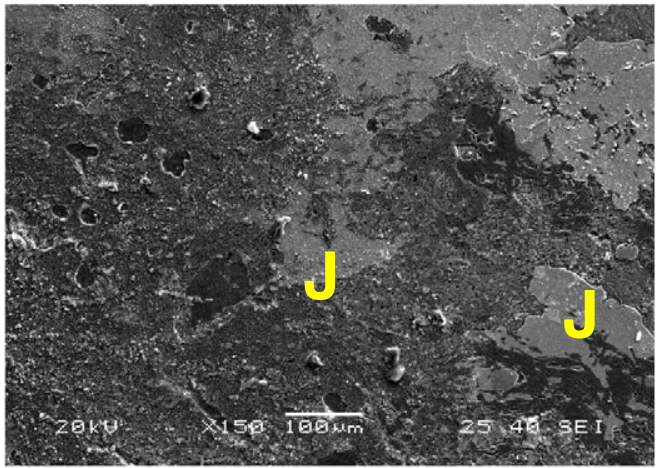

d

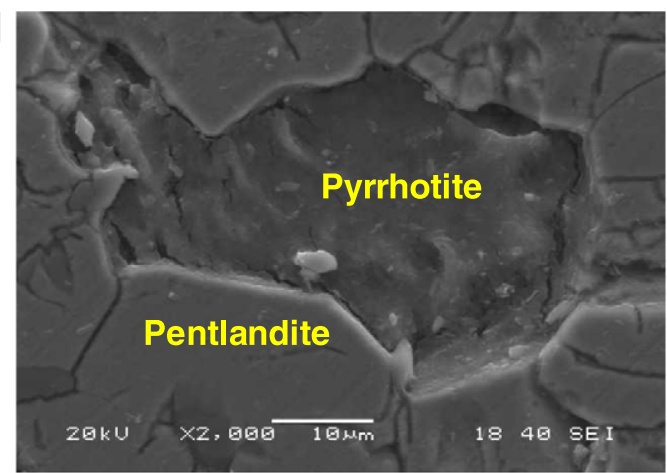

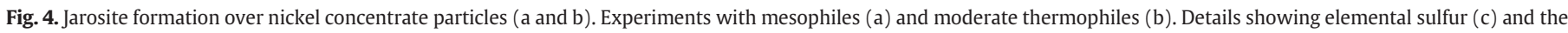
preferential dissolution of a pyrrhotite particle (d) while the pentlandite region is less attacked. J: jarosite, S: elemental sulfur.

pyrrhotite, it also means higher leaching rates, assuming that the indirect mechanism describes the start of the leaching process.

\subsection{Leaching thermodynamics}

The improved bioleaching kinetics and efficiency at higher temperatures could be ascribed to the thermodynamics of the process, as well as to leaching kinetics. Leaching thermodynamics is traditionally addressed through Eh-pH diagrams, which show stability fields for selected species and are a useful tool in sulfide leaching studies, providing insight on the greater bioleaching efficiency observed with $S$. thermosulfidooxidans. Fig. 7 depicts the Eh-pH diagrams for iron- and nickel sulfides calculated from thermodynamic data at $50{ }^{\circ} \mathrm{C}$. The predominant areas of pyrrhotite and potassium jarosite is presented in Fig. 7a, in which pyrite $\left(\mathrm{FeS}_{2}\right)$ is

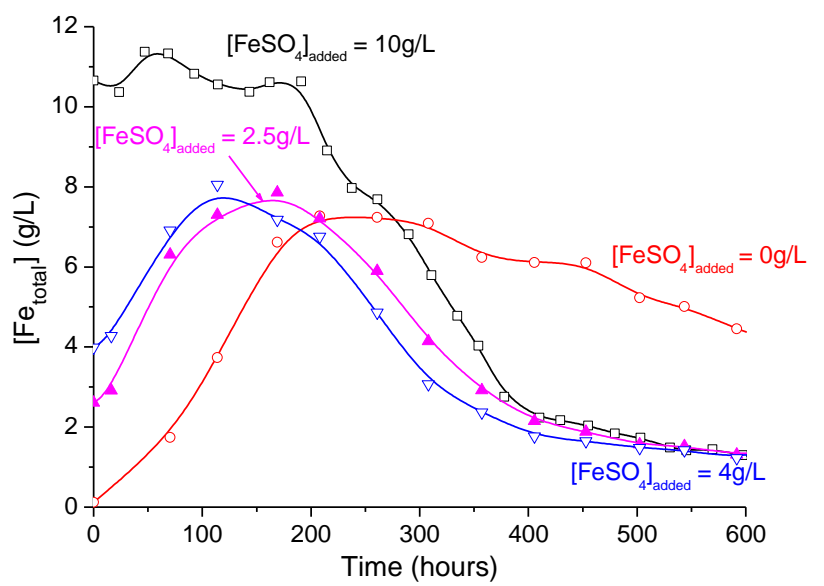

Fig. 5. Effect of $\mathrm{FeSO}_{4}$ addition on total iron concentration during bioleaching of nickel concentrate with moderate thermophile $\left(5 \% \mathrm{w} / \mathrm{v}, \mathrm{pH} 1.6,50{ }^{\circ} \mathrm{C}\right)$. omitted to highlight the stability field of pyrrhotite. Clearly, pyrrhotite is not stable in acid solutions, decomposing to jarosite under oxidizing conditions above $\mathrm{pH}$ 2-as easily detected during bioleaching (Fig. 4a). Compared to Eh-pH diagrams at $25^{\circ} \mathrm{C}$, temperature only has a minor effect on the stability region of pyrrhotite and jarosite under bioleaching conditions.

However, temperature has an important role on the kinetics of jarosite formation. Activation energies for jarosite precipitation were determined by Dutrizac (1996), who also compiled data available in the literature. The author found activation energy values of around $100 \mathrm{~kJ} / \mathrm{mol}$, and the precipitation was much slower in the absence of seeds. Faster iron(II) oxidation and jarosite precipitation can be inferred from the iron concentration profile during bioleaching at both $34{ }^{\circ} \mathrm{C}$ and $50{ }^{\circ} \mathrm{C}$ (Figs. 3 and 6). As pyrrhotite dissolution provides enough iron(II) for bacterial growth (Rodríguez et al., 2001), the

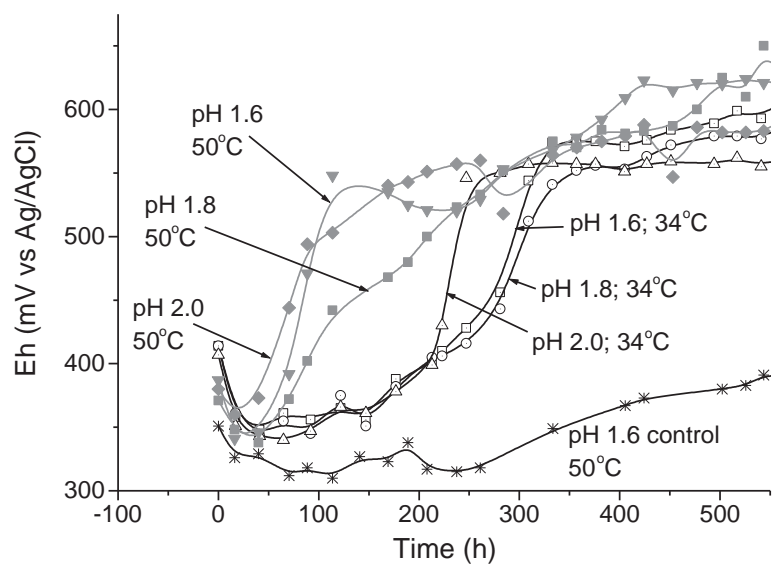

Fig. 6. Effect of $\mathrm{pH}$ on solution potential during the bioleaching of nickel concentrate by a (a) mesophile iron-oxidizing culture $\left(5 \% \mathrm{w} / \mathrm{v},[\mathrm{Fe}(\mathrm{II})]_{\text {initial }}=2.5 \mathrm{~g} / \mathrm{L}, 34^{\circ} \mathrm{C}\right)$ and $(\mathrm{b})$ moderate thermophile $\left(5 \% \mathrm{w} / \mathrm{v},[\mathrm{Fe}(\mathrm{II})]_{\text {initial }}=2.5 \mathrm{~g} / \mathrm{L}, 50{ }^{\circ} \mathrm{C}\right)$. 
a

\section{Eh (Volts)}

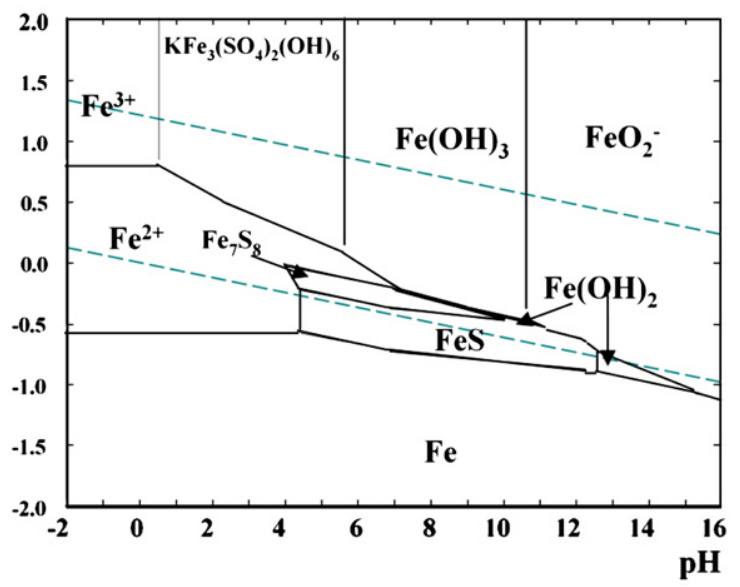

b

\section{Eh (Volts)}

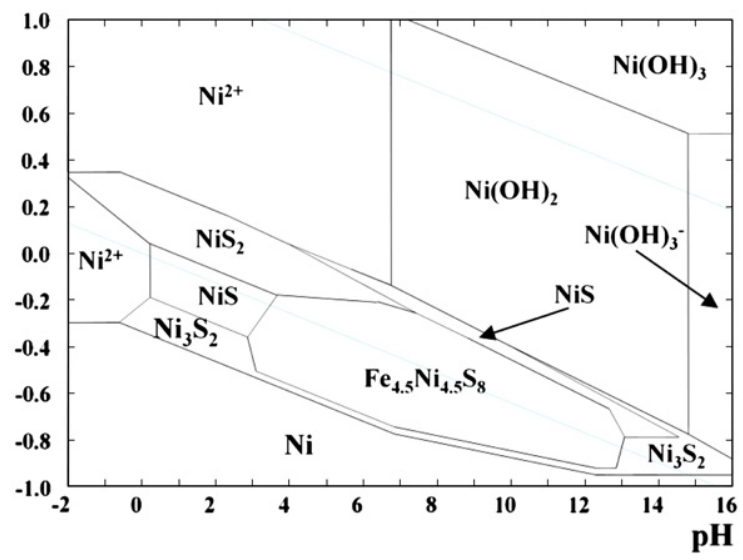

Fig. 7. Eh-pH diagram from pyrrhotite (a) and pentlandite (b). Temperature: $50{ }^{\circ} \mathrm{C}$; concentration of dissolved species: $10^{-3} \mathrm{~mol} / \mathrm{L}$ (a) and $10^{-2} \mathrm{~mol} / \mathrm{L}(\mathrm{b})$.

external iron(II) addition must be properly managed so that an ideal iron concentration is maintained in the bioleaching system; otherwise, jarosite formation could negatively impact bioleaching. This is especially true with moderate thermophiles (Fig. 2).

Eh-pH diagrams were also plotted for the system $\mathrm{Ni}-\mathrm{S}-\mathrm{H}_{2} \mathrm{O}$. This was more challenging, since free energy of formation values for pentlandite are not easily available, especially in temperatures other than $25^{\circ} \mathrm{C}(298 \mathrm{~K})$. Therefore, pentlandite's free energy of formation $\left(-813 \mathrm{~kJ} / \mathrm{mol}\right.$, at $\left.25^{\circ} \mathrm{C}\right)$ proposed by Warner et al. (1996), along with its standard enthalpy of formation $\left(-837.37 \mathrm{~kJ} / \mathrm{mol}\right.$, at $\left.25^{\circ} \mathrm{C}\right)$ (Waldner and Sitte, 2008), were used to estimate the entropy of formation for nickel sulfide. Afterwards, using these values, both the enthalpy and entropy of formation were determined at $50{ }^{\circ} \mathrm{C}$ with the help of the Cp data proposed by Berezovskii et al. (2001), and fitted to the following equation:

$C p=1998.3+3.19 T+\frac{53.72 \times 10^{6}}{T^{2}}$

It must be stressed that the Berezovskii et al. (2001) data only covered the $6-34{ }^{\circ} \mathrm{C}$ range and that the $\mathrm{Cp}$ equation was then assumed to be valid up to $50{ }^{\circ} \mathrm{C}$, i.e., Eq. (1) was extended to that temperature. Thereafter, entropy and enthalpy of formation were determined for the following chemical reaction:

$4.5 \mathrm{Fe}(\mathrm{s})+4.5 \mathrm{Ni}(\mathrm{s})+8 \mathrm{~S}(\mathrm{~s})=\mathrm{Fe}_{4.5} \mathrm{Ni}_{4.5} \mathrm{~S}_{8}$
Following this procedure, the standard free energy of formation for pentlandite was estimated at $50{ }^{\circ} \mathrm{C}$ as $-810.9 \mathrm{~kJ} / \mathrm{mol}$. This value was then used in the Eh-pH diagram presented in Fig. 7. Pentlandite is the predominant nickel sulfide species, decomposing to different nickel sulfides $\left(\mathrm{NiS}_{2}, \mathrm{NiS}\right.$ and $\left.\mathrm{Ni}_{3} \mathrm{~S}_{2}\right)$ at a lower $\mathrm{pH}$, which is consistent with the work of Warner et al. (1996). At very high acidities, nickel ions and $\mathrm{H}_{2} \mathrm{~S}$ (Warner et al., 1996) could be produced directly from pentlandite. Again, temperature has a negligible effect on the nickel-sulfide field stabilities in the range $25-50{ }^{\circ} \mathrm{C}$.
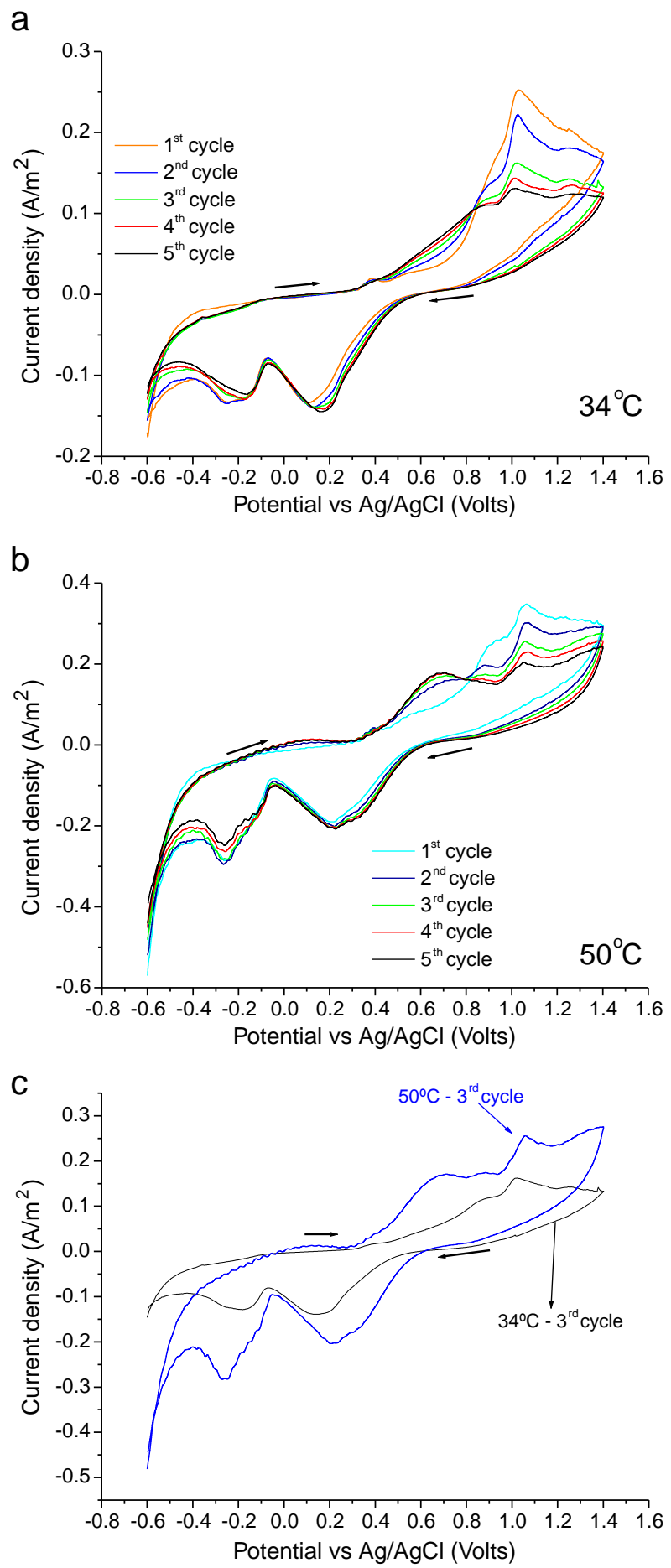

Fig. 8. Cyclic voltammetry spectra for the mixed pentlandite-pyrrhotite ore. Experimental conditions: carbon paste electrodes, $50 \mathrm{mV} / \mathrm{s}, 1 \mathrm{~mol} / \mathrm{L} \mathrm{H}_{2} \mathrm{SO}_{4}$. 


\subsection{Cyclic voltammetry studies}

Cyclic voltammetry was applied to shed some light on the mixed sulfide oxidation kinetics. The mixed mineralogy of the nickel concentrate hinders a detailed interpretation of the spectra presented in Fig. 8, but some of its features are also observed in the spectra of pure pyrrhotite (Mikhlin, 2000; Nicol and Scott, 1979) (especially) and pentlandite (Warner et al., 1992).

The spectra shown in Fig. 8a and b are fairly similar, irrespective of the temperature studied. Going in the anodic direction, peaks are observed near $0 \mathrm{~V}$, which appears only from the second cycle onwards. This is consistent with the oxidation of the $\mathrm{H}_{2} \mathrm{~S}$ produced in the previous scan during the cathodic sweep; as proposed by both Mikhlin (2000) and Warner et al. (1992). Another peak is observed at $0.4 \mathrm{~V}$, and it has been suggested that in this potential range, either elemental sulfur layers or irondepleted surface FeS coatings are formed as a result of pyrrhotite oxidation (Mikhlin, 2000). Furthermore, according to Cruz et al. (2005), the peak at $\sim 1.0 \mathrm{~V}$ for pyrrhotite implies that the passive layer is broken and the polysulfide (or elemental sulfur) is oxidized to sulfate. Alternatively, this peak could be assigned to pentlandite oxidation and subsequent $S^{0}$ formation (Warner et al., 1992).

In the reduction sweep, a catholic peak is observed at $0.2 \mathrm{~V}$, reportedly assigned to the reduction of ferric oxyhydroxides to $\mathrm{Fe}^{2+}$ species. Another larger peak at about -0.2 to $0.3 \mathrm{~V}$ was assigned to the reduction of elemental sulfur to $\mathrm{H}_{2} \mathrm{~S}$ (Mikhlin, 2000; Nicol and Scott, 1979; Warner et al., 1992), regardless of the sulfide nature (pyrrhotite or pentlandite). At both temperatures, it is worth noting (Fig. 7b) that in the fifth cycle, there is a broad passive region, starting at $\sim 0.6 \mathrm{~V}$ along with a decrease in the magnitude of the current density at $\sim 1.0 \mathrm{~V}$, which is not observed in the first cycle. This decrease in the current density for successive cycles indicates either a reduction in the electrode surface area, or more likely, that the oxidation products formed in the first cycles are passivating the electrode (Warner et al., 1992).

The most striking feature shown in Fig. 8 is observed in the peak observed at $04-0.8 \mathrm{~V}$, where an increase in current density is observed up to the third cycle, leveling out in the last two sweeps. In this region, an increase of $22 \%$ and $73 \%$ of current density at $34{ }^{\circ} \mathrm{C}$ and $50{ }^{\circ} \mathrm{C}$, respectively, is observed, highlighting the effect of temperature on the pyrrhotite oxidation process. This is reinforced in Fig. 8c that shows a larger increase in the current density (at $0.4 \mathrm{~V}$ and above) at $50{ }^{\circ} \mathrm{C}$ as compared to that observed at $34{ }^{\circ} \mathrm{C}$. Furthermore, Fig. $8 \mathrm{c}$ also shows higher current densities associated with pentlandite oxidation $(\sim 1.0 \mathrm{~V})$ when both temperatures are compared. Accordingly, the higher current density values observed at $50{ }^{\circ} \mathrm{C}$ support the faster nickel bioleaching observed with S. thermosulfidooxidans.

\section{Conclusions}

Temperature has a beneficial effect on nickel sulfide bioleaching and greater and faster nickel dissolution is achieved with $S$. thermosulfidooxidans as compared to A. ferrooxidans. Nickel dissolution occurs at $34{ }^{\circ} \mathrm{C}$, after most of the iron has been leached, suggesting a galvanic effect. Moderate thermophiles provide faster Eh increase $\left(\mathrm{Fe}^{2+}\right.$ oxidation) and result in pyrrhotite and pentlandite being dissolved simultaneously with improved nickel leaching kinetics. Eh-pH diagrams plotted for both minerals showed no significant effect of temperature on the stability fields of both minerals. However, temperature increases sulfide oxidation kinetics as suggested by cyclic voltammetry performed on the mixed sulfide. The indirect mechanism seems to be effective in the beginning of the leaching cycle as a result of massive iron dissolution, but as $\mathrm{Fe}^{3+}$ concentration reduces due to jarosite precipitation and elemental sulfur is formed, the direct mechanism becomes important, especially in the final leaching steps.

\section{Acknowledgements}

The financial support from the funding agencies FINEP, FAPEMIG, CNPq, and CAPES as well as Votorantim Metais is gratefully appreciated. The "Conselho Nacional de Pesquisas" - CNPq scholarship to V. A. Leão is also acknowledged. The assistance of Ms. H.K. Reis is also kindly appreciated.

\section{References}

Alves, L., Bernardelli, C., Teixeira, M., Lima, H., Donati, E., 2009. Microbial diversity in acid mine drainage and experimental bioleaching leaching environments revealed by culture independent methods. In: Donati, E., et al. (Ed.), IBS 09-International Biohydrometallurgy Symposium. Trans Tec, Bariloche, pp. 173-177.

Berezovskii, G.A., Drebushchak, V.A., Kravchenko, T.A., 2001. Low-temperature heat capacity of pentlandite. American Mineralogist 86 (10), 1312-1313.

Berry, V.K., Murr, L.E., Hiskey, J.B., 1978. Galvanic interactions between chalcopyrite and pyrite during bacterial leaching of low-grade waste. Hydrometallurgy 3 , 309-326.

Blázquez, M.L., Álvarez, A., Ballester, A., González, F., Muñoz, J.A., 1999. Bioleaching behaviour of chalcopyrite in the presence of silver at $35^{\circ} \mathrm{C}$ and $68{ }^{\circ} \mathrm{C}$. In: Amils, R., Ballester, A. (Eds.), Biohydrometallurgy and the Environment Toward the Mining of the 21st Century. Elsevier, Madrid, Spain, pp. 137-147.

Cruz, R., González, I., Monroy, M., 2005. Electrochemical characterization of pyrrhotite reactivity under simulated weathering conditions. Applied Geochemistry 20 (1), 109-121.

Deveci, H., Akeil, A., Alp, I., 2004. Bioleaching of complex zinc sulphides using mesophilic and thermophilic bacteria: comparative importance of $\mathrm{pH}$ and iron. Hydrometallurgy 73, 293-303.

Dew, D., Buuren, C.V., McEwan, K., Bowker, C., 2000. Bioleaching of base meta sulphide concentrates: a comparison of high and low temperature bioleaching. Journal of the South African Institute of Mining and Metallurgy 100 (7), 409-414.

Dutrizac, J.E., 1996. The effect of seeding on the rate of precipitation of ammonium jarosite and sodium jarosite. Hydrometallurgy 42 (3), 293-312.

Hallberg, K.B., Johnson, D.B., Langwaldt, J., Joulian, C., 2007. Microbial populations in a 110 ton-scale column for the recovery of metals from black schist ores. Advanced Materials Research 170-170 579-579.

Hansford, G.S., Vargas, T., 2001. Chemical and eletrochemical basis of bioleaching processes. Hydrometallurgy 59, 135-145. doi:10.1016/S0304-386X(00)00166-3.

Kuklinskii, A.V., Mikhlin, Y.L., Pashkov, G.L., Kargin, V.F., Asanov, I.P., 2001. Conditions of the formation of non-equilibrium nonstoichiometric layer on pyrrhotite in acid solutions. Russian Journal of Electrochemistry 37, 1269-1276.

Lu, Z.Y., Jeffrey, M.I., Zhu, Y., Lawson, F., 2000. Studies of pentlandite leaching in mixed oxygenated acidic chloride-sulfate solutions. Hydrometallurgy 56 (1) 63-74.

Marhual, N.P., Pradhan, N., Kar, R.N., Sukla, L.B., Mishra, B.K., 2008. Differential bioleaching of copper by mesophilic and moderately thermophilic acidophilic consortium enriched from same copper mine water sample. Bioresource Technology 99 (17), 8331-8336.

Mason, L.J., Rice, N.M., 2002. The adaptation of Thiobacillus ferrooxidans for the treatment of nickel-iron suphide concentrates. Minerals Engineering 15 795-808.

Mehta, A.P., Murr, L.E., 1983. Fundamental studies of the contribution of galvanic interactions to acid-bacterial of mixed metals sulfides. Hydrometallurgy 9, 235-256.

Mikhlin, Y., 2000. Reactivity of pyrrhotite surfaces: an electrochemical study. Physical Chemistry Chemical Physics 2, 5672-5677.

Nicol, M.J., Scott, P.D., 1979. The kinetics and mechanism of the non-oxidative dissolution of some iron sulfide species in aqueous solutions. Journal of the South African Institute of Mining and Metallurgy 79 (10), 298-305.

Pina, P.S., Leão, V.A., Silva, C.A., Daman, D., Frenay, J., 2005. The effect of ferrous and ferric iron on sphalerite bioleaching with Acidithiobacillus sp. Minerals Engineering 18 (5), 549-551.

Pogliani, C., Donati, E., 2000. Immobilisation of Thiobacillus ferrooxidans: importance of jarosite precipitation. Process Biochemistry 35, 997-1004.

Riekkola-Vanhanen, M., 2007. Talvivaara Black Schist Bioheapleaching Demonstration Plant. Advanced Materials Research 20-21, 30-33.

Rodríguez, Y., Ballester, A., Blásquez, M.L., González, F., Muñoz, J.A., 2001. Basic studies on bioleaching of chalcopyrite, sphalerite and pyrite. In: Cimininelli, V.S.T., Garcia Jr., O. (Eds.), International Biohydrometallurgy Symposium. Ouro Preto, Brazil, Elsevier, pp. 125-138.

Sand, W., Gehrke, T. Gorg Jozsa, P., Schippers, A., 2001. (Bio)chemistry of bacterial leaching-direct vs. indirect bioleaching. Hydrometallurgy 59 (02-03), 159-175.

Santos, L.R.G., Barbosa, A.F., Souza, A.D., Leao, V.A., 2006. Bioleaching of a complex nickel-iron concentrate by mesophile bacteria. Minerals Engineering 19 (12), 1251-1258,. doi:10.1016/j.mineng.2006.03.001.

Santos, L.R.G., Barbosa, A.F., Souza, A.D., Leao, V.A., 2008. Nickel sulphide oxidation by mesophile bacteria. Rem-Revista Escola De Minas 61 (1), 39-46. 
Schippers, A., Jozsa, P.G., Sand, W., 1996. Sulfur chemistry in bacterial leaching of pyrite. Applied and Environmental Microbiology 62 (9), 3424-3431.

Semenza, M., Viera, M., Curutchet, G., Donati, E., 2002. The role of Acidithiobacillus caldus in the bioleaching of metal sulfides. Latin American applied research 32, 303-306.

Waldner, P., Sitte, W., 2008. Thermodynamic modeling of Fe-Ni pentlandite. Journal of Physics and Chemistry of Solids 69 (4), 923-927.

Warner, T.E., Rice, N.M., Taylor, N., 1992. An electrochemical study of the oxidative dissolution of synthetic pentlandite in aqueous media. Hydrometallurgy 31 (1-2), 55-90,. doi:10.1016/0304-386x(92)90108-c.
Warner, T.E., Rice, N.M., Taylor, N., 1996. Thermodynamic stability of pentlandite and violarite and new EH-pH diagrams for the iron-nickel sulphur aqueous system. Hydrometallurgy 41 (2-3), 107-118,. doi: doi:10.1016/0304-386x(95)00081-q.

Watling, H.R., 2008. The bioleaching of nickel-copper sulfides. Hydrometallurgy 91 (1-4), 70-88.

Yang, X., Zhang, X., Fan, Y., Li, H., 2008. The leaching of pentlandite by Acidithiobacillus ferrooxidans with a biological-chemical process. Biochemical Engineering Journal 42 (2), 166-171. 